DARKO LEITNER-STOJANOV

Institute of National History

University of Ss. Cyril \& Methodius in Skopje

d_stojanov_sk@hotmail.com
UDC: $930.2(3) " 652 / 653 "(091)$

UDK: 930(3):001(497.7)"1944/1991"

\title{
PRODUCTION OF KNOWLEDGE ON LATE ANTIQUITY IN SOCIALIST MACEDONIA (1944-1991)
}

\begin{abstract}
The paper provides quantitative assessment of academic research on Late Antiquity by analyzing three main historical and archeological journals from socialist Macedonia (Review of the Institute for National History, Macedoniae Acta Archeologica and History). Its primary goal is to locate the production of knowledge and its fluctuations in various years, departments and journals. Its second goal is to shed light on the wider political and academic contexts in which that production of knowledge took place. Chronologically, the survey of the journals continues for two more decades after the fall of Socialism and the proclamation of Macedonian independence, in order to include a comparative aspect. The results show a significant difference in the production of knowledge between archaeologists and historians, that cannot be explained by simply pointing to Ideology.
\end{abstract}

\section{Introduction}

This paper ${ }^{1}$ aims at understanding the modalities of production of knowledge on Late Antiquity in the particular academic and political context of the Socialist Republic of Macedonia, and is a part of a larger investigation of the perceptions of the ancient and medieval past in the politics and discourse of socialist Yugoslavia. It tries to map the production of knowledge on Late Antiquity, as well as to explain the main factors which shaped its form and content. The key question posed in the text is: To what extent and in which academic fields was Late Antiquity researched in socialist Macedonia? I believe that a quantitative assessment of the source material, could lead to a better understanding not only of the academic achievements in that particular research field, but also of the cultural policies of the Socialist Republic of Macedonia regarding the ancient and medieval past.

In the center of this analysis is the Academic Institution, understood as a field of power, i.e. as a social space where political, academic

${ }^{1}$ This article is based on a working paper for the project Repräsentationen des sozialistischen Jugoslawien im Umbruch: Entwicklungen seit den 1970er Jahren, led by Humboldt University in Berlin in 2014. 
and economic powers intersect, as well as a space of creating power in its own right. Research on the late antiquity in Macedonia was conducted, on different levels and with different approaches, at the (people's) museums across the country whose members joined forces in the Archaeological Society of the Socialist Republic of Macedonia based in Prilep, as well as at the Institute of National History and the University of Saints Cyril and Methodius in Skopje. Discussing this academic social space in the frames of our project, presupposes making relations with the Yugoslav socialist ideology and politics (especially the Marxist interpretation of history, the regional diplomatic relations, the "Brotherhood \& Unity" etc.) on the one hand, and with the advancements in the larger international field of Late Ancient studies on the other. Somewhere in the middle of these larger concepts is the individual, the "Homo Academicus" with his/her cultural capital, as a crucial player in the production of knowledge in these academic institutions. Keeping in mind these three points is an important moment in any effort to interpret the production of knowledge in that particular setting.

It should be further stressed that "Late Antiquity" in the title can be seen as a chronological, as well as a conceptual reference. In its first aspect, Late Antiquity reflects a contemporary academic perception of a "historical period" which goes approximately from AD 300 to 600, and is seen as a time sequence, a mere chronological orientation. In its second aspect, Late Antiquity is a cultural and academic concept which is based on particular views on the history of the Mediterranean civilization(s), which claims that in the above mentioned period there was a substantial number of processes and elements which in many aspects can legitimize approaching them as a particular "late ancient" phenomenon. Furthermore, the concept suggests that the period in question is no longer to be seen as a simple continuation of the ancient word, and certainly not as its long lasting decadence. ${ }^{2}$ Since Late Antiquity is a relatively recent concept in contemporary historiography (from the early 70's onwards), and at the same time the research done in socialist Macedonia is quite limited, it was impossible for this paper to focus solely on the conceptual aspect of the term. The accent here is rather on the late ancient period.

\section{Production of knowledge on Late Antiquity: a quantitative assessment of relevant academic journals}

The output of the research on the late antiquity in Macedonia was published in several academic journals. In socialist times they appeared (and still do) as articles in journals dedicated to the fields of

\footnotetext{
${ }^{2}$ It is widely acknowledged that the pioneer in this field is Peter Brown with his seminal book The World of Late Antiquity AD 150-750, London, 1971. For similar ideas published in French, cf. Henri-Irénée Marrou, Décadence romaine ou antiquité tardive?, Le Seuil: Paris, 1977. Both Brown (in the 1960's) and Marrou (in the 1930's) did their doctoral research on Augustine of Hippo.
} 
history or archeology in general, so the number of papers dealing with Late Antiquity differed from issue to issue. Most of these papers appeared in the mainstream and more widely read journals such as: the Review of the Institute for National History (Гласник на Институтот за национална историја, since 1957), the journal History (Исmopuja, since 1965) and the Macedoniae Acta Archeologica (since 1975). Some articles may have appeared in other journals, such as the local reviews of the regional people's museums across the country, but their production and audience was even more limited than those mentioned above and they were not as influential as the mainstream, discourse shaping, bigger academic journals, which at least in Yugoslav times were printed in thousands and had the chance to reach a wider audience (as opposed to the same journals today which are published in a significantly smaller number). In order to get a better insight into the production of knowledge on Late Antiquity, in this section a detailed survey is presented of the three journals mentioned above. The focus is on: the number of issues that contain articles on Late Antiquity, the number of articles on Late Antiquity, as well as the quantitative relation between these articles and those on other historical periods. Additionally, in some cases, in order to get a broader perspective, I followed these statistics well into the period of post-socialist, independent, Republic of Macedonia.

\section{a. Review of the INH ("Glasnik")}

The Review of the Institute for National History was established in 1957, almost ten years after the foundation of the Institute by a governmental decree. It was the first mainstream relevant historical journal in socialist Macedonia. It provided a platform for systematic and permanent publication of current research results in historiography. However, even before that crucial date, historiographical works were being published in the country. In fact, 402 bibliography units appeared in the period 1948-1956, on a variety of subjects, not limited to academic ones. ${ }^{3}$-Among them, 58 publications dealt with the ancient and medieval past, ${ }^{4}$ _and among them only three touched upon the late antiquity, mostly because their focus was on the important Roman city of Stobi. One would expect that the establishment of the Review might change that situation.

So far, in its 57 years of existence, the Review published 106 volumes, containing one or (sometimes) two issues. For the purposes of this paper, I have investigated 101 out of 106 volumes $(95 \%$ of the Review), dating from 1957 to 2012, with a special focus on the socialist

${ }^{3}$ Cf. Istoriografijata vo N.R. Makedonija od osloboduvanjeto do krajot na 1956 godina, GINI I/1 (1957), 341-367 (= Historiography in the P.R. of Macedonia from its liberation until the end of 1956).

${ }^{4}$ Surprisingly (or not) only three of those came from the Institute for National History. 
period. Of those, 72 volumes were produced in socialist Macedonia (up to 1991). Unfortunately, four issues from the 1970's were not available to me. Yet, I believe that the percentage of the volumes/issues covered here is sufficient for analysis and could offer some valid results, important for further research.

From the 72 volumes, 31 contain articles (50) on medieval history, while 8 contain articles (10) on ancient history. Of the later, only 5 articles deal with topics from the late ancient period.

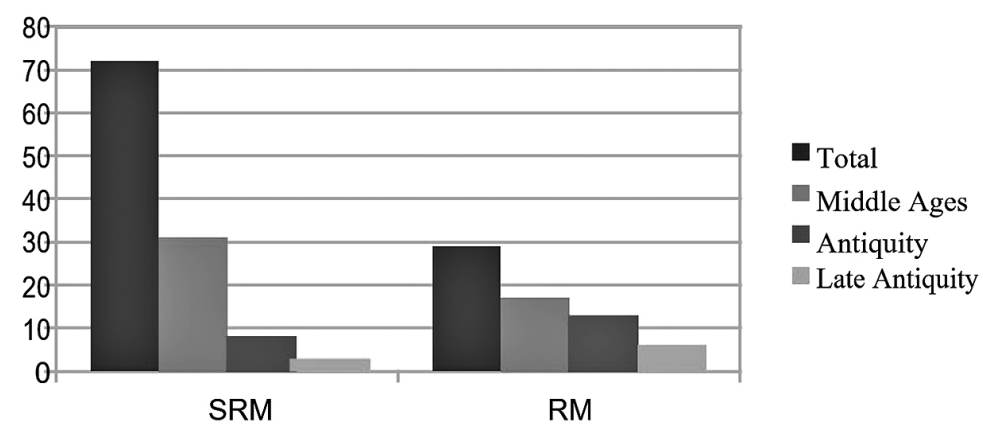

Review of INH:volumes containing articles on Antiquity and Middle Ages

(and a comparison between SRM and RM)

It appears that discussing ancient history was a rare event in the Review during socialist times. When it comes to Late Antiquity, two things are easily noticeable in this chart. First, the minimal number or volumes which have at least one article on Late Antiquity, and second, the minimal amelioration of this situation in the immediate post-socialist period. The representation of ancient and medieval history, in general, is steadily increasing in recent times, but is still far from that of modern and contemporary history. With six volumes (out of 29 in total) which contain articles on Late Antiquity, one could argue that the production of knowledge on that particular historical period is still at a very low level, at least if we follow the Review.

If we take a closer look at the material dedicated particularly to medieval and ancient history, we can see that the largest portion of it (around 77\%) deal with the Middle Ages. The rest of it refers to Antiquity in general. To be more precise, only five articles (among hundreds) in 72 volumes published in 34 years actually deal with questions from the late ancient period. This can only lead us to the sad conclusion that the Review of the Institute of National History, while playing a minimal role in advancing the studies on Antiquity, in fact had no real contribution to the study of Late Antiquity. 


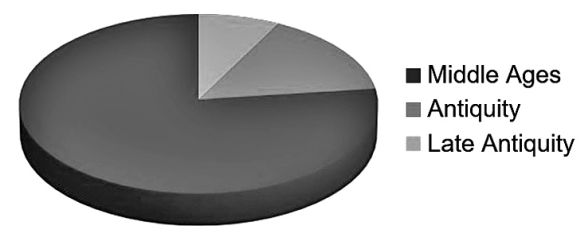

Review of INH: Correlation between articles on Middle Ages, Antiquity and Late Antiquity in SRM

Those five articles, which symbolically represent the attention (not) given to Late Antiquity, focus on military history (1959), archeology (1967), numismatics (1982), and urbanism/fortification (1990), and were published rather by archaeologists (as well as one classical philologist). Only the first article from 1959 dealing with the Slavic sieges of Thessalonica in the $6^{\text {th }} / 7^{\text {th }} \mathrm{c}$. was actually written by an individual who six years later defended a doctoral dissertation on the Balkan socialists and the Macedonian question. This points to the lack of trained historians in periods other than the national "revival" and the antifascist \& national liberation war in the $19^{\text {th }} / 20^{\text {th }}$ century - a point that we shall return to later.

As a comparison, in the period after the proclamation of Macedonia's independence (1991) generally speaking, there has been a small, but important increase, and articles on Late Antiquity are more frequent. This does not imply that the progress was linear. In fact, in the first 15 years of independence the old trend continued. Then, since 2005 the attention to the period in question became more stable and continuous.

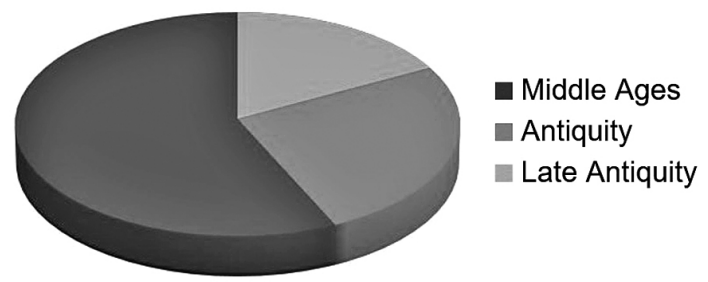

Review of INH: Correlation between articles on Middle Ages and Antiquity in RM

On the basis of the statistics presented so far, one could argue that the main historical journal in socialist Macedonia (the Review of the Institute of National History) did not pay particular attention to the late ancient past of the region, i.e. that the academic staff of the institute did not yet invest in developing that research field. This attitude continued well into independent Macedonia, and it is only in the last 15 years that historians in Macedonia began doing more substantial 
research in that field, at least in terms of numbers and attention. In any case, it is worth stressing that in the last decade there is a balance in the number of articles on Antiquity, Late Antiquity and Middle Ages in the Review.

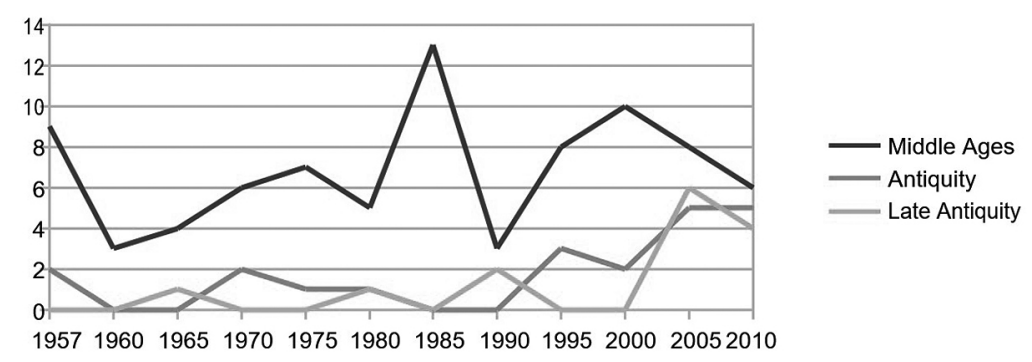

Review INH: Articles on Middle Ages, Antiquity and Late Antiquity (1957-2012)

\section{b. History (since 1965)}

A second relevant academic journal for history studies appeared eight years after the Review. In 1965, the Union of the Historians' Associations of the Socialist Republic of Macedonia started publishing its journal with a special focus on history teaching and historiography. ${ }^{5}$ Although principally an academic journal, Istorija also targeted a wider audience of history teachers in the country. Thus, besides articles, it also offered discussions and updates on contemporary teaching methods and new teaching materials.

Without going into detailed statistics like in the previous case, I would simply point that Istorija also published a minimal number of articles on the late ancient period. In 25 years of existence in the socialist period, the journal published 8 such articles, again all of them written by archaeologists. ${ }^{6}$ This leaves us with the same conclusion as

${ }^{5}$ The finances were provided by the government, i.e. by the Secretariat for education, science and culture at the Executive Council of the SRM, and later on by subscription as well, cf. Izvestaj za rabotata na redakcijata na spisanieto Istorija, Istorija III/1 (1967), 206 and Izvestaj za rabotata na redakcijata na spisanieto Istorija, Istorija V/1 (1969), 311. On its didactic orientation cf. N. Dimovski, Spisanieto Istorija i nastavata po istorija, Istorija X/2 (1974), 496-503.

${ }^{6}$ I have surveyed Istorija's articles for the period 1970-1991, therefore its first five volumes are unfortunately not represented in my assessment, and might change (although not significantly) the total number of articles on Late Antiquity. For an insight in Istorija's publications, cf. R. Poplazarov, Bibliografija na trudovite i na site drugi naslovi objaveni vo Istorija od br. 1, VI god. do br. 2, X god. (1970-1974), Istorija X/2 (1974), 553-570; A. Ilievski, Bibliografija na trudovite i na drugite naslovi objaveni vo spisanieto Istorija vo vremenskiot interval od 1974-1984 godina, odnosno od br. 1, XI god. do br. 1, XX god., Istorija XX/2 (1984), 521-551; and D. Jovanovski, Bibliografija na trudovite i drugite naslovi objaveni vo spisanieto Istorija od 1984 do 1994, odnosno od broj 2, god. XX do broj 1-2, god. XXX, Istorija XXXI/XXXII / 1-4 (1995/1996), 147-169. 
in the case of the Review. It appears that in the socialist period historical academic journals in Macedonia did not have a relevant production of articles on Late Antiquity. The rare cases were actually published by archaeologists. Therefore, we shall briefly turn to an analysis of the leading archaeological journal published in socialist, as well as postsocialist, Macedonia.

\section{c. Macedoniae Acta Archeologica (since 1975)}

MAA was the organ of the Archaeological Society of the Socialist Republic of Macedonia. ${ }^{7}$ It is still a very relevant forum for archaeological publication and discussion in the country. The journal was launched in 1975, and it was administered and edited in Prilep, but printed in Belgrade. For most of the socialist period, it was published as a joint effort between the People's Museum of Prilep and the Union of Archaeological Societies of Yugoslavia based in Belgrade. In general, MAA contained the research results of the annual archaeological symposiums organized in different cities in Macedonia. Its first editor in chief was the archaeologist Bosko Babić, while its first editorial team was consisted of Blaga Aleksova, Ivan Mikulčić, Vojislav Sanev and Vera Bitrakova. This start up seems to offer a different view on the research of Late Antiquity, not only because we are dealing with archaeologists, but also because two (and even three) of them actually did substantial work on that period - Aleksova became prominent with her research in Stobi, while Mikulčić focused on late ancient fortifications and urban settlements.

I have surveyed $87 \%$ of the MAA issues, for the period up to 2014. Only the last three issues from 2011 onwards are not represented in this paper. Again, I believe that this percentage gives a valid insight into MAA's research tendencies. What is very different in relation to the two historical journals mentioned above, is that Late Antiquity is represented in all the issues of MAA. A survey of the articles from the socialist period shows a very different situation in regard to the attention to the late ancient period. In fact, it is clear that in socialist Macedonia archaeologists were much more familiar with Late Antiquity than historians. Their production takes a significant portion of the archaeological research, and together with the rest of the Antiquity in fact they dominate that field. While, prehistoric archaeology is also doing quite well, we can see that research on Middle Ages is lacking (especially if we compare it with its position in the production of the historical Review of the INH at the same time period).

The material dealing with Late Antiquity in MMA (in socialist times) relates to a variety of topics and approaches. These include, but are not limited to late antique: topography, rescue archeology, urban

${ }^{7}$ Today, this society is called Macedonian Archaeological Scientific Society, and it is based in Skopje. 
dwellings, Christian architecture (basilicas), numismatics, rural properties, necropolis, mining, fortifications etc. It covers the entire territory of the Socialist Republic of Macedonia, although the leading large-scale research at the time was done at the archeological site of Stobi. Most of the publications were a result of local, national initiatives, but several were international projects involving partners especially from the USA and Poland.

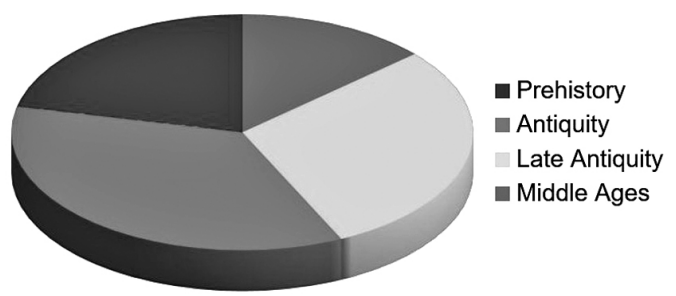

MMA: Correlation between articles on Prehistory, Antiquity, Late Antiquity and Middle Ages (in SRM)

The dynamics of this production is also quite relevant for this case study. It appears that the number of papers on Late Antiquity is significant for that time period, but its frequency is not stable and does not show any particular patterns which we can easily relate to a political context. On the contrary, I believe that here, as in the case with Antiquity, we are dealing with the human factor in a rather spontaneous manifestation. Simply, a society with just a limited number of archaeologists on Late Antiquity cannot keep a high production in that field every consecutive year. The ups and downs in the following table are in fact quite logical.

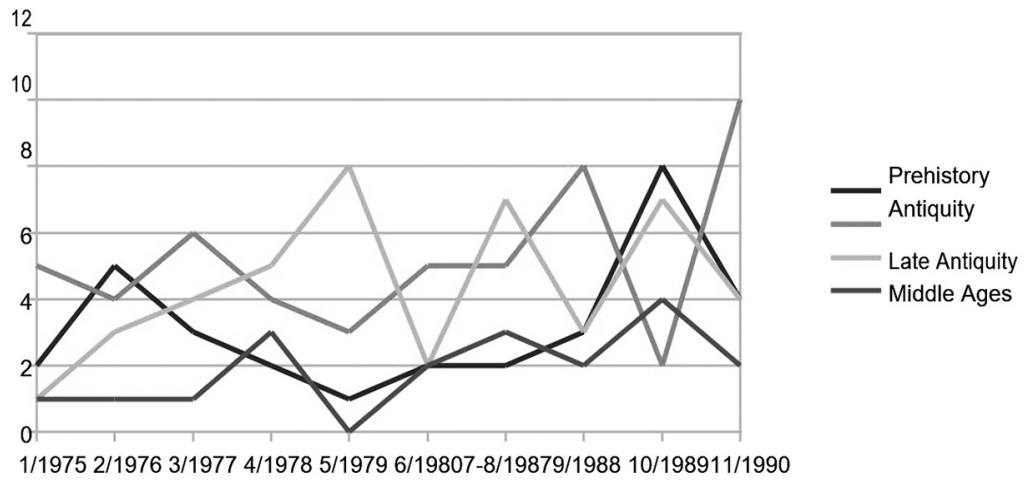

MMA: dynamics of production (in SRM) 
This chart represents the overall number of articles on Late Antiquity published in relevant academic journals, both historical and archaeological, in socialist Macedonia. What is striking right away is the fact that the vast majority of those articles were published by archaeologists in MAA (44 papers). On the other side, we have articles published also (mostly) by archaeologists in the Review (5) and Istorija (8) - journals which gave only a minor contribution in understanding that particular historical period. Having in mind this disparity in the production, one immediate question emerges: why didn't the historians manage to provide more substantial results in that aspect? This will lead us to the academic and educational context of socialist Macedonia.

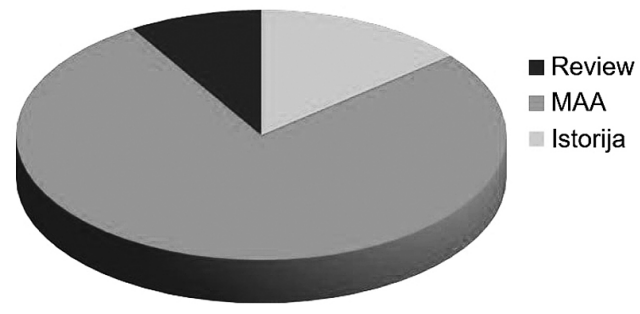

Researching Late Antiquity in Socialist Macedonia: INH Review vs. MAA vs. Istorija

\section{Academia and education: Buildup of research capacities}

Rapports from several reunions of historians in socialist Macedonia testify for a serious lack of academic staff. On some occasions the problem was the weak training and the low research skills of the young candidates, but on other occasions the problem was not having any staff at all. In a discussion surrounding the establishment of the Review, in 1957, several participants pointed, among other things, ${ }^{8}$ to the lack of research staff for certain historical periods as an important impediment for the work of the historiographical profession. Blaže Koneski, a leading intellectual figure of those times, accentuated his worries about the overall academic merit of the current generations of students of history. ${ }^{9}$ He argued that although the university study group for history has a satisfying number of students, only a few of them showed capacities for academic work. He called for a better selection process, and for investing in excellent high-school students, as a way of ameliorating the level of historical research in the country. ${ }^{10}$

\footnotetext{
${ }^{8}$ Most of the discussions referred rather to the "struggle for cleaning up the history of the Macedonian people", the "Marxist scientific view on history", the need to "present to the World the truth of the Macedonian people", but also to the need for coordination between institutes, for restoration of cultural monuments etc. 338.

${ }^{9} \mathrm{Cf}$. the short anonymous paper "Discussion upon the rapports", GINI 1 (1957), ${ }^{10}$ Ibidem.
} 
Similar appeal for support for young historians was made by H. Andonovski as well, who at the time was one of the first doctoral candidates (later a leading Yugoslav/Macedonian historian). The most prominent communist political leaders were well aware of this particular issue. L. Mojsov, for example, claimed that the work of the institute cannot even be imagined without an influx of a proper number of young "scientific workers", and proposed an employment of at least 15 to 20 new young historians and other collaborators. ${ }^{11}$ The lack of research staff remained an acute problem even decades later. In 1969, in professional reunions, historians (such as the university professor V. Kuševski) still argued for the need of investment in the education of young historians. ${ }^{12}$

Needless to say, Antiquity (including late antiquity) and Middle Ages were certainly the most understaffed sections, but it is important to stress that in the 1950's even the very fashionable, promising and politically relevant modern and contemporary history fields were also understaffed. Simply, there were not enough specialists in the country from which the Institute might choose its potential researchers. In the first twenty years of the functioning of the Institute the lack of academic staff was an essential and most serious problem for its stable functioning. The first significant wave of doctoral promotions in historiography, a result of the investments done after the raised concerns in the late 1950's, arrived only in 1965.

\section{Doctoral dissertations in history (1958-1983) ${ }^{13}$}

Surveying the doctoral program in history can provide an important insight into the problem of the lack of trained researchers in history of the Late Antiquity. The period between 1958 and 1983 saw thirty defenses of doctoral dissertations in history, at the department of

${ }^{11}$ Lazo Mojsov, Za idnite zadaci na institutot za nacionalna istorija, GINI 1 (1957), 331. He referred several times to this need in his paper. Mojsov will later on rise to the highest political position in Yugoslavia, heading both the Presidency of SFR Yugoslavia and the Presidency of the League of Communist of Yugoslavia.

${ }^{12} \mathrm{Cf}$. the rapport by H. Melovski, Za rabotata na Godisnoto sobranie na Sojuzot na istoriskite drustva na SRM (Stip, 28-29 septemvri 1968 godina), Istorija V/1 (1969), 315.

13 All the data about this issue comes from A. Ilievski, Pregled na odbraneti doktorski disertacii, magisterski tezi I diplomski raboti od oblasta na istoriskite nauki na NNSG za istorija na Filozofskiot fakultet vo Skopje do 31.XII 1983 godina, Istorija XIX/2 (1983), 357-368. The sources for Ilievski's survey were selected from the archives of the chair of history and of the faculty of philosophy. He provides an important insight into the origin, age, and the academic interest of the candidates. A similar overview, which provides additional insight, was done more than 15 years earlier as well, cf. A. Apostolov, Osvrt na odbranetite doktorski disertacii so istoriska problematika na Filozofskiot fakultet vo Skopje od negovoto sozdavanje do krajot na 1965 godina (Po povod dvaesetgodisninata od sozdavanjeto na Filozofskiot fakultet vo Skopje), Историја II/2 (1966), 171-177. 
history at the University of Saints Cyril and Methodius in Skopje (i.e. the only place which produced academic historians in the republic). From these, more than half (13) were defended in 1965 (most of them in December that year), which is probably the largest wave of doctoral promotions in history in a single year in socialist Macedonia. ${ }^{14}$ However, what is relevant for our case study is that none of these dissertations was dealing with late ancient history; all of them focused on $19^{\text {th }} / 20^{\text {th }}$ century. Besides that, the department did not produce new doctors in historical studies in the next 8 years. ${ }^{15}$ When the promotions proceeded later on, there was still no candidate interested in Late Antiquity. In total, out of those 30 dissertations in the period 19581983: a. 12 focused on contemporary history, b. 15 on modern history (most of them on $19^{\text {th }}$ century national or socialist/communist ideas and movements in Macedonia), and c. 3 on (Late) Middle Ages. Basically, no one specialized on a period prior to AD 1000, i.e. there is absolutely nothing on Antiquity, Late Antiquity or Early Middle Ages. Dissertations on medieval history focus on the late Middle Ages and are indeed a rare event - once per decade. Thus, specializing in preOttoman history was rather incidental, and specializing in antiquity or late antiquity was virtually non-existing in the capital of socialist Macedonia. This, of course, leaves us with many questions.

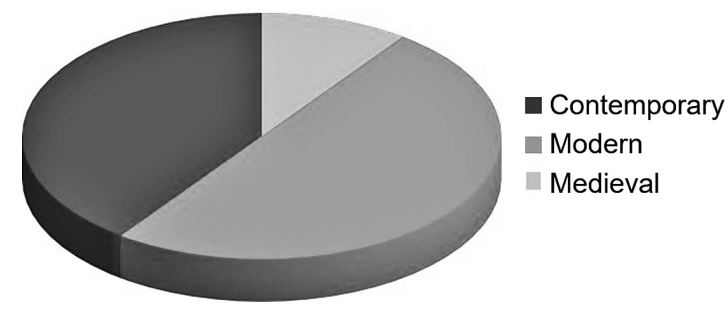

$\mathrm{PhD}$ thesis in history (1958-1983)

Probably the most important in this context would be: a. Why the university or even the government did not, or could not, or did not want to invest in the formation of a critical body of historians on ancient or medieval history, including Late Antiquity; and b. Why the students did

14 This influx of Doctors is certainly related to the previous appeals and efforts to invest in a buildup of research capacities, but it is in fact a direct result of a very pragmatic situation. As of January $1^{\text {st }} 1966$, a new law on doctoral studies would require all $\mathrm{PhD}$ candidates to possess a Master degree in order to be eligible for obtaining the title of Doctor, cf. A. Apostolov, Osvrt, 172. This was not the case thus far. Therefore, in 1965 candidates were in a hurry to finish their thesis as soon as possible. Those who made it are now considered to be the first generation of Macedonian historians.

15 The only exception was the 66 years old candidate who in 1969 defended a thesis on socialism in $19^{\text {th }}$ century Vojvodina, cf. A. Ilievski, Pregled, 361. 
not, or could not, or did not want to specialize in ancient and medieval history, including Late Antiquity.

\section{Between the political and the academic context}

In general, since the independence of the country (1991), and especially in the last several years, which saw a shift in the nationbuilding process and a radical turn towards the ancient past, it was common for conservative politicians, as well as intellectuals, to attribute the responsibility for the lack of studies in ancient history solely to the former socialist political elite, both Macedonian and Yugoslav. The reason for this was located in the political need for keeping the cohesion between the Slavic speaking Yugoslav republics, as well as in maintaining good political relations with neighboring Greece in the South. At the same time, the role of institutional and self-censorship has been stressed. Although this line of reflection is indeed quite logical, yet analysis of primary sources is lacking and those claims are often taken for granted.

Thus, one must call for an awareness of the variety of reasons and factors which could have led to the neglect of historical research on ancient and medieval history in general, and Late Antiquity in particular. I believe that the explanation of the problem is much more complex than usually presented in academic or public discourse. ${ }^{16}$ One should further look into issues such as: the lack of interest and even the students' efforts to avoid studying ancient languages (which are necessary for a specialization in those time periods), the effort of some professors to keep a monopoly in their research field, the relations of power in the academic milieu, as well as other phenomena such as opportunism and nepotism. The academic institution, it is well known, is not only a place for academic training and production of knowledge, but also a social space for power relations. It is a place where the individual or Bourdieu's Homo Academicus ${ }^{17}$ _can gain significant cultural (even material) capital and eventually exercise symbolic violence over others. Three kinds of symbolic capital are in a permanent struggle at the university: academic, scientific, and intellectual power. ${ }^{18}$ The first one relates to the power of control over the administration of academic resources, the second to scholarly reputation based on publications, and the third one to the power to influence

${ }^{16}$ For a similar view, with an analysis focused on Medieval/Byzantine studies, cf. I. Stefoska, Nation, Education and Historiographic Narratives: the Case of the Socialist Republic of Macedonia (1944-1991), in: U. Brunnbauer and H. Grandits (eds), The Ambiguous Nation. Case Studies from Southeastern Europe in the $20^{\text {th }}$ Century, Oldenbourg Verlag: Munchen, 2013, 211-213.

${ }^{17}$ P. Bourdieu, Homo Academicus, Paris, 1984.

${ }^{18}$ Cf. G. Delanty, Challenging Knowledge. The University in the Knowledge Society, The Society for Research into Higher Education \& Open University Press, 2001, 93. 
public opinion through scholarly discourse (and today much more through mass media). ${ }^{19}$

\section{Conclusion}

Taking into consideration the political, economic and academic context in socialist Macedonia, there is a significant (although not rich) production of knowledge on the late ancient past of the region. This production is minor in comparison with the research done on the modern and contemporary history, but it is however quite relevant. This contribution to academic understanding of the late ancient period was produced entirely by the archaeologists of the time. Historians played no role in that aspect, since they were rather focused on periods and topics related to the national(ist) and socialist/communist ideas, deemed more relevant for political legitimization. International projects, such as the American-Yugoslav joint excavations, turned some archaeological sites (Stobi) into major focus point for late ancient studies.

On the other hand, the concept of Late Antiquity as established by Peter Brown in 1970's was still not debated in socialist Macedonia. Having in mind the recent establishment of that idea, as well as the level of research on the late ancient period in the country, it is not a surprise that its introduction in Macedonia would come later.

As to the contemporary perception of the attitude of the SRM towards the late antique past, one can argue that recent claims by politicians and intellectuals that the socialist government "forbade" and "blocked" research on (Late) Antiquity are not entirely valid, i.e. they are incomplete, at the very least. The research done by archaeologists provides another perspective to this issue. Furthermore, the insight into the education, and especially at the doctoral dissertations of that time, shows that the department of history at the university did not manage to produce enough, if at all, research staff for historical study of the period. Whether this is due to political-ideological reasons, or to the lack of qualified professors, or to the lack of interest by the students, or any other reason, is a still an open and valid question, that deserves scholarly attention.

${ }^{19}$ Ibidem. 
